\title{
Selective predation by a harpacticoid copepod on ciliates in phytotelmata: a laboratory experiment
}

\author{
Krzysztof Wiackowski • Wioleta Kocerba-Soroka
}

Received: 8 December 2015/Revised: 31 July 2016/Accepted: 1 August 2016/Published online: 17 August 2016

(C) The Author(s) 2016. This article is published with open access at Springerlink.com

\begin{abstract}
Copepods are the most numerous metazoans in water-filled phytotelmata formed by Heliconia and Calathea floral bracts in cloud forests of Cordillera de la Costa, Northern Venezuela. We estimated the potential effect of copepods on ciliate community structure in this habitat with a laboratory experiment. Predation effects of five life stages of a harpacticoid copepod on a mixed culture of five bacterivorous ciliate species were measured during a 48-hour incubation. The predation effect depended on copepod life stage and on ciliate prey species. The abundances of Colpoda inflata, Tetrahymena pyriformis, and Colpidium kleini were significantly reduced, the actual effect strongly depending on copepod developmental stage. No detectable predation was observed on Paramecium aurelia or Tachysoma pellionellum. The results suggest that predation by harpacticoid copepods is an important factor influencing ciliate community structure in phytotelmata.
\end{abstract}

Keywords Calathea Container habitats · Ingestion rate $\cdot$ Meiofauna $\cdot$ Protists

Handling editor: John Havel

K. Wiackowski $(\bowtie) \cdot$ W. Kocerba-Soroka Institute of Environmental Sciences, Jagiellonian University, Gronostajowa 7, 30-387 Kraków, Poland e-mail: k.wiackowski@uj.edu.pl

\section{Introduction}

Humid tropical forests are famous for their extraordinary biodiversity and spatial complexity. Water-filled reservoirs created by leaves of certain plants provide a special type of aquatic habitat (Kitching, 2000). Tank bromeliads very abundant in the forest canopy and brightly coloured Heliconia and Calathea inflorescences in the better lit understory areas, are very characteristic features of the Neotropical forests. Such 'plant containers' (phytotelmata) harbour communities of aquatic organisms even far away from any pond or river. Sugden \& Robins (1979) estimated the total volume of water held in epiphytic tank bromeliads in a Colombian cloud forest as about 50,000 L per hectare. Consequently, the aquatic communities in the forest canopy represent an important and often overlooked component of the tropical forest biodiversity.

Aquatic communities in plant-held waters consist of diverse organisms from bacteria to vertebrates. Macro-invertebrates have so far been the most extensively studied inhabitants of phytotelmata (Seifert \& Seifert, 1979; Frank \& Lounibos, 1983; Richardson, 1999; Kitching, 2000) with mosquitoes receiving particular attention (Seifert, 1980; Frank, 1983; Naeem, 1988; Greeney, 2001). Much less is known about the composition and functional roles of the meiofauna, among which copepods are of primary importance. Harpacticoid copepods seem to display a particular preference for this type of habitat as 20 
species, out of 28 so far recorded from phytotelmata, have never been observed in any other habitat (Jocque et al., 2013).

Although protozoans are very common in various phytotelmata, only recently have they attracted serious attention from taxonomists. Studies focusing on tropical plant-held reservoirs have recently resulted in many new species and higher-rank ciliate taxa (Foissner et al., 2003; Foissner, 2010, 2013; Foissner \& Stoeck, 2013; Foissner et al., 2014). Molecular analyses carried out on samples from neotropical phytotelmata reveal many unknown and possibly endemic species (Dunthorn et al., 2012). Although factors affecting protozoan distribution and community structure in plant-held waters remain basically unknown, predation is certainly one of the most important. It has been shown that mosquito larvae are able to significantly reduce, or even completely eliminate, ciliates in both natural and artificial container habitats (Maguire, 1963, 1971; Vandermeer et al., 1972, Addicott, 1974). The effects of other potential consumers of protozoans have rarely been documented in phytotelmata. However, given the numerical importance of copepods in this habitat, one can expect that their predation on protists might be significant. The importance of the copepod-ciliate trophic link has been well documented in both marine and freshwater plankton (Wiackowski et al., 1994; Wickham, 1995a, b; Calbet \& Saiz, 2005). The ciliatecopepod trophic relationship in pelagic habitats is considered an important part of the microbial-loop, linking both primary and bacterial production to the higher trophic levels (Sherr et al., 1986).

In contrast to the plankton, the relationship between benthic copepods and ciliates has been much less studied (Reiss \& Schmid-Araya, 2011; Cnudde, 2013). In particular, little is known about harpacticoid feeding in freshwater habitats (Sarvala, 1998). Marine harpacticoid copepods have been shown to consume a wide range of food sources, including bacteria, exopolymer substances, microalgae, flagellates, ciliates, fungi and yeasts (Rieper \& Flotow, 1981; Hicks \& Coull, 1983; Rieper, 1985). Most studies have focused on harpacticoids as consumers of diatoms and/ or bacteria, demonstrating some degree of selectivity in their feeding (Chepurnov, 1987; Perlmutter \& Meyer, 1991; De Troch et al., 2005, 2006; Wyckmans et al., 2007). Although significant ontogenetic changes in copepod size, morphology and behaviour must inevitably lead to diet shifts, in most feeding studies only the adult copepods were taken into consideration. Data on the trophic function of nauplii and copepodites, typically more abundant than the adult stage, are still very limited (Decho \& Fleeger, 1988; Kumar \& Rao, 1998; Muylaert et al., 2006).

Aquatic communities in phytotelmata are usually based on detritus (Kitching, 2000). In Heliconia and Calathea spp, numerous inconspicuous flowers develop under the water in each bract. The flowers bloom successively rising above the water level. Decaying flowers strongly enrich the water with decomposing organic matter. Allochthonous detritus also increases the basic food resources available for aquatic biota. Habitats rich in decaying organic matter usually contain high abundances of ciliates and other heterotrophic protists grazing on bacteria. However, water samples taken from Calathea casupito (Jacq.) G. Mey (Marantaceae) and Heliconia bihai (L.) L. (Heliconiaceae) floral bracts in the cloud forest of Cordillera de la Costa (Venezuela) contained surprisingly low densities of protozoans in spite of large amounts of accumulated detritus (K. Wiackowski, personal observation). This observation suggests that their abundances may be controlled by predation. Although mosquito larvae were not always observed in small bract containers of $C$. casupito, copepods were always present in high densities with nauplii and copepodites being always the most abundant stages. Since an unidentified harpacticoid (Canthocamptidae) was by far the most abundant metazoan, it seemed to be the most likely predator to control the ciliate community in this habitat.

In order to evaluate this supposition, the predation effect of the copepod, isolated from a $C$. casupito bract on a five-species ciliate culture, was measured under laboratory conditions. The effects of five different life stages of the copepod (two nauplii, two copepodites and the adult) were compared. We hypothesized that (i) the copepod predation on ciliates would be significant; (ii) the predation effect of various copepod life stages would differ in both quantitative and qualitative terms and (iii) ciliate species would differ in their susceptibility to copepod predators.

\section{Methods}

An unidentified harpacticoid copepod was isolated from a water-filled floral bract of $C$. casupito growing 
in close proximity to the Biological Station (Rancho Grande), located in the cloud forest in Henri Pittier National Park, Cordillera de la Costa, Venezuela. The sample was taken in August, 2008. Copepods were maintained in small $(5 \mathrm{~cm}$ diameter) Petri dishes to which two rice grains were added to stimulate the growth of bacteria. Several drops of a dense culture of the bacterivorous ciliate Colpidium kleini Foissner were added two times per week. Every two weeks, copepods were transferred into new dishes. Commercially available spring water (“Żywiec zdrój”) (https://www.zywiec-zdroj.pl/) was the basic medium in all cultures and experiments.

A mixed culture of ciliates isolated from the same sample was used in the experiment. The culture contained three bacterivorous ciliates: Colpoda inflata (Stokes) Kahl (length 40-90 $\mu \mathrm{m}$ ), Paramecium aurelia Ehr. $(100-180 \mu \mathrm{m})$ and Tachysoma pellionellum (O.F.M.) Borror $(55-100 \mu \mathrm{m})$. This community was further supplemented with two other bacterivorous ciliate species: C. kleini $(70-120 \mu \mathrm{m})$ and Tetrahymena pyriformis Ehr. (40-60 $\mu \mathrm{m})$ from cultures kept in the laboratory. These are common bacterivorous species also frequently observed in various phytotelmata in the area of Rancho Grande (K. Wiackowski, personal observation). Ciliate species were identified using Foissner et al. (1991, 1994). Cultures were maintained in a similar way to the copepods, i.e. by supplementing with rice grains to stimulate the growth of bacteria. All Petri dishes were kept in an environmental chamber at constant temperature of $20^{\circ} \mathrm{C}$, in darkness.

Several weeks before the experiment, females carrying egg sacs were isolated into separate dishes. When nauplii appeared a few days later, the females with eggs and the juvenile forms were isolated into separate dishes. Nauplii were fed with bacteria in the way described above. This isolation process was repeated during following days. New nauplii were isolated while subsequent copepod stages developed in separate dishes. Since the first appearance of the copepodites, their diet was supplemented with $C$. kleini as described above. In this way, five different developmental stages of the copepod were made available for the experiments: two nauplii, two copepodites and adult (Table 1).

Three days before the experiment, ciliate cultures from several dishes were mixed together in a single
Erlenmeyer flask and left without food in order to minimize the potential effect of bacteria on the copepods during the experiment. The experiment was carried out in tissue culture plates (TPP) with flat-bottom wells, each $3.5 \mathrm{~cm}$ in diameter. At the beginning of the experiment, each well was filled with $2 \mathrm{ml}$ of mixed ciliate culture. A single copepod of appropriate life stage was introduced into each treatment well. Each treatment was replicated five times. Plate wells were randomly assigned to the treatments. The control treatment contained only ciliates without copepods. The experiment, with slightly different initial ciliate abundances, was carried out twice within a five-day interval.

On the first day of each experiment, the initial number of ciliates was counted in a separately prepared set of five wells. Before counting, the well contents were fixed with 4 drops of Bouin's fluid (Foissner, 1991), and the ciliates were allowed at least two hours to settle after preservation. Fixed ciliates lying on the well bottom were counted in 10 randomly selected vision fields at a magnification of $200 \times$. Counting was done with an inverted microscope (Olympus IMT-2). The total initial ciliate abundance was $1827 \pm 233$ ind. $\mathrm{ml}^{-1}$ (mean $\pm \mathrm{SD}$ ) in the first and $2132 \pm 356$ ind. $\mathrm{ml}^{-1}$ in the second experiment.

The experimental plates were incubated $48 \mathrm{~h}$ at $20^{\circ} \mathrm{C}$ in the dark. The contents of each well was then fixed and counted as described above. In case of $C$. inflata, both "active" and encysted ciliates were counted. The copepod predation effects were estimated by means of one-way ANOVA, on each ciliate species separately. The analysis was carried out on coefficients of population growth rate, calculated as $r=\left(\ln N_{T}-\ln N_{O}\right) / T$, where $\ln N_{T}$ and $\ln N_{O}$ are natural logs of the final and initial population sizes, and $T$ is 2 days. Tukey's test was used to estimate the statistical significance of the differences between treatment pairs. The ingested ciliate biomass was estimated following the method described by Reiss \& Schmid-Araya (2011).

\section{Results}

The results of the two independent experiments were very similar (Figs. 1, 2; Tables 2, 3). After 48-h incubation, in both experiments, statistically significant effects of copepod predation were observed on $C$. 
Table 1 Age and size (mean $\pm \mathrm{SD}, n=3$ ) of the harpacticoid copepod used in the present work

\begin{tabular}{lcrr}
\hline Stage & Age (days) & Length $(\mu \mathrm{m})$ & Width $(\mu \mathrm{m})$ \\
\hline N-1 (early nauplius) & 5 & $261.5 \pm 21.8$ & $208.1 \pm 15.1$ \\
N-2 (late nauplius) & 13 & $340.4 \pm 18.5$ & $264.3 \pm 31.4$ \\
C-1 (early copepodite) & 22 & $506.7 \pm 19.1$ & $305.9 \pm 44.4$ \\
C-2 (late copepodite) & 34 & $921.7 \pm 17.6$ & $356.2 \pm 21.3$ \\
Adult (female) & 46 & $1560.5 \pm 56.4$ & $422.4 \pm 91.0$ \\
\hline
\end{tabular}

The numbers 1 and 2 used in the first column refer to early versus late developmental stages and not to specific naupliar and copepodite instars

inflata, C. kleini and T. pyriformis. No detectable predation was observed on P. aurelia or T. pellionellum. Estimated ingestion rates of ciliate numbers and biomass for different copepod life stages are shown in Table 4.

The effect of the copepods on C. kleini was significant and highly dependent on the developmental stage in both experiments (Figs. 1, 2). Only the adult copepods and copepodites strongly reduced C. kleini abundance. The effect of the older naupliar stage was statistically significant only in one experiment. Statistically, the treatments with the remaining juvenile stages did not differ significantly from the control. In contrast to Colpidium, the abundance of the smaller $T$. pyriformis was strongly reduced only by the younger copepod stages. The older of the two naupliar stages (N-2) ingested significantly more $T$. pyriformis than the copepodites and the adult forms (Figs. 1,2).

The abundance of the active $C$. inflata was more strongly reduced in the treatments with older copepod stages. However, the number of the cysts showed an opposite trend. Their number tended to be higher in those treatments where the predation effects on the active $C$. inflata was stronger. However, only in one of the two experiments was the difference in cyst number statistically significant (Fig. 2).

\section{Discussion}

As all ciliate species used in our experiments are bacterivorous (there are no published reports on these ciliates eating other ciliates), most probably they did not directly affect their abundances. Although we cannot completely discount competition effects, the way each ciliate species increased their abundance in control treatment, compared to their initial numbers (Figs. 1, 2), indicates that copepod predation was the main factor responsible for the observed differences among treatments.

The results demonstrate that the predation of ciliates by the harpacticoid copepod was highly selective. The abundances of some ciliate species were significantly reduced, this effect being strongly dependent on the copepod life stage. The stronger effect of the older (larger) development stage of the copepod on Colpidium kleini, for example, could be expected. It has previously been shown that larger copepods usually select for larger prey since the latter make stronger disturbances in the water and are thus easier perceived by copepods, which use mechanoreceptors to detect their prey (Kiørboe \& Visser, 1999). Wiackowski et al. (1994) also observed that larger ciliates were more often attacked than the smaller ones by adult planktonic copepods. Similarly, Azovsky et al. (2005) reported that an adult harpacticoid selected larger diatoms.

The younger nauplii treatment $(\mathrm{N}-1)$ was never statistically different from the control, indicating that even the smallest ciliates were probably too large for this small juvenile stage to ingest. However, it is also possible that the effect was too weak to be observed under the conditions of this experiment (i.e. a single copepod per well). Interestingly, in the case of the smallest ciliate Tetrahymena pyriformis, the predation of the older nauplii (N-2) turned out to be significantly stronger than that both of the copepodites and the adult forms. The observed clear difference in feeding between the older nauplius and the younger copepodite can probably be explained by the great difference between these two body forms. Epp \& 

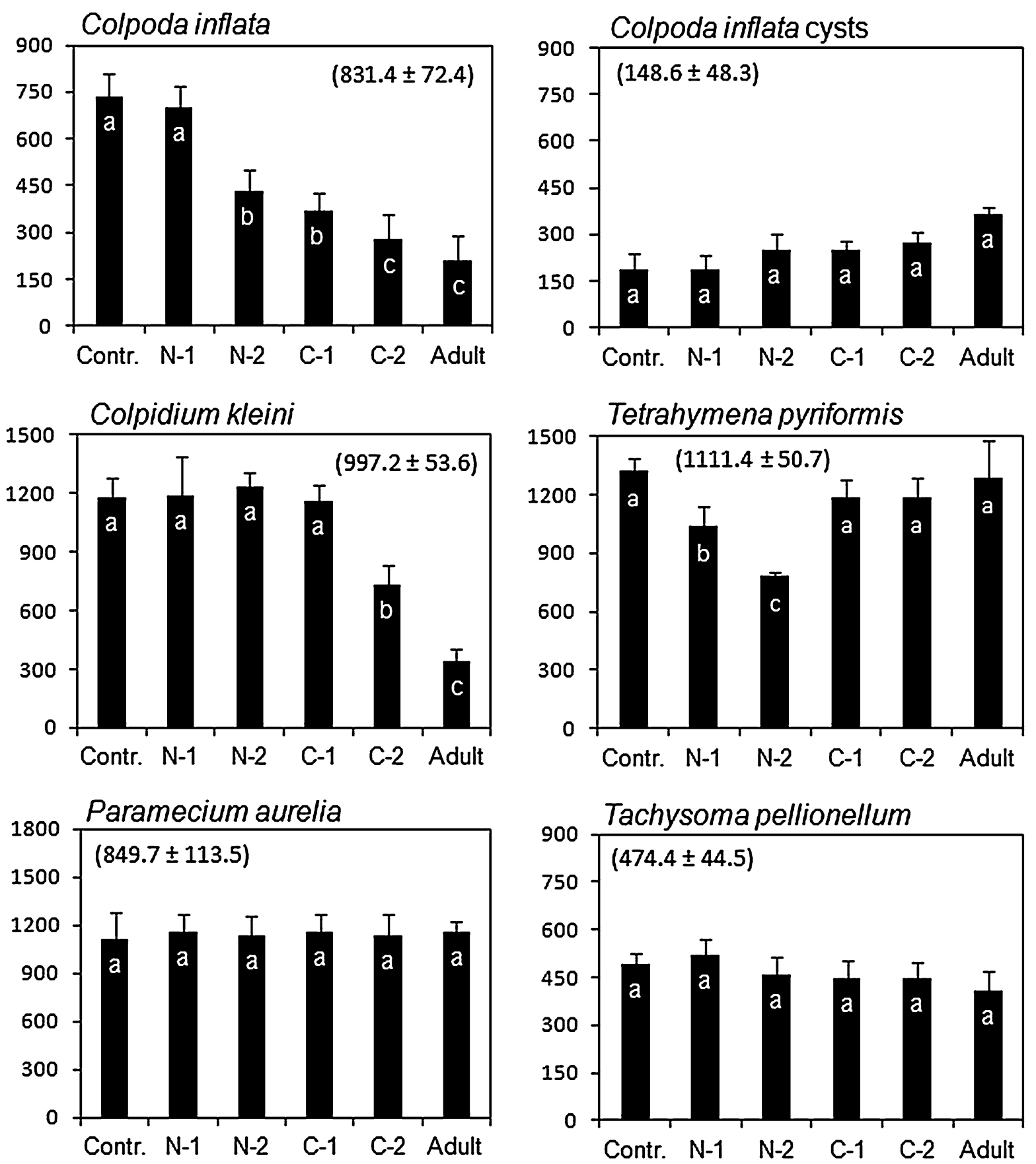

Fig. 1 Ciliate abundances in the first experiment after 48-h incubation with different developmental stages of a harpacticoid copepod: Contr. (control without copepods), N-1 (younger nauplius), $\mathrm{N}-2$ (older nauplius), $\mathrm{C}-1$ (younger copepodite), $\mathrm{C}-2$ (older copepodite). Numbers in parentheses indicate initial

Lewis (1980) have shown that nauplii and copepodites have a very different metabolic weight relationship, which is a consequence of radical changes in

ciliate abundances (mean $\pm \mathrm{SD}$ ). Different letters on the histograms denote statistically different treatments according to Tukey's test ( $P<$ experiment-wise $\alpha=0.05$ ). Mean values $\pm \mathrm{SD}$ of five independent replicates are presented

morphology, locomotion, behaviour and nutrition, accompanying the transformation from nauplius to copepodite. 

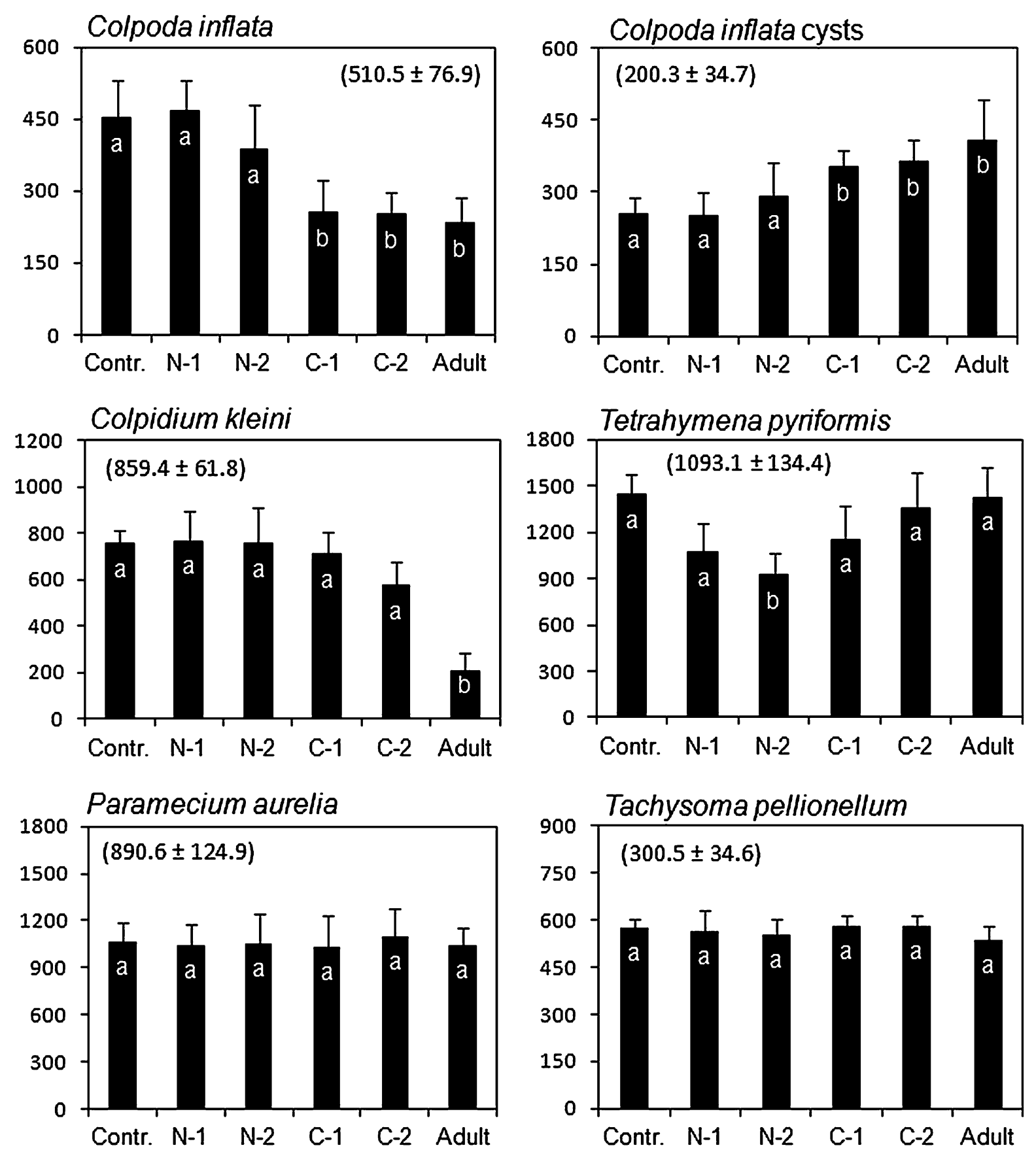

Fig. 2 Ciliate abundances in the second experiment after 48-h incubation with different developmental stages of a harpacticoid copepod. All designations as in Fig. 1

Although the total number of ciliates ingested per unit time was not correlated with the size of the copepod, such a tendency is clearly visible for the ingested biomass. The larger forms always consumed larger ciliate biomass per unit time (Table 4). This was due to the fact that the older stages selected for larger ciliates in spite of the presence of the abundant smaller species (Figs. 1, 2). This result suggests that the copepods behaved as predicted by the optimal foraging theory, by selecting prey that maximized their 
Table 2 The results of one-way ANOVAs on ciliate population growth rates for five copepod treatments (developmental stages presented in Table 1) plus the non-copepod control for experiment 1 (Fig. 1)

\begin{tabular}{llllcc}
\hline Ciliate species & SS & DF & MS & $F$ & $P$ \\
\hline Colpoda inflata & 1.6605 & 5 & 0.3321 & 25.1897 & 1.2641 \\
Colpoda inflata (cysts) & 0.4146 & 5 & 0.0829 & 0.001 \\
Colpidium kleini & 1.5691 & 5 & 0.3138 & 0.0003 & 0.0374 \\
Paramecium aurelia & 0.0017 & 5 & 0.0085 & 1.2967 & 0.001 \\
Tachysoma pellionellum & 0.0427 & 5 & 0.0465 & 21.7225 & 0.2982 \\
Tetrahymena pyriformis & 0.2329 & 5 & & $<0.001$ \\
\hline
\end{tabular}

Error $d f=24$

Table 3 The results of one-way ANOVAs on ciliate population growth rates for five copepod treatments (developmental stages presented in Table 1) plus the non-copepod control for experiment 2 (Fig. 2)

\begin{tabular}{llllcr}
\hline Ciliate species & SS & DF & MS & $F$ & $P$ \\
\hline Colpoda inflata & 0.6603 & 5 & 0.1320 & 11.06 & 6.6686 \\
Colpoda inflata (cysts) & 0.2559 & 5 & 0.0511 & 0.001 \\
Colpidium kleini & 1.8324 & 5 & 0.3664 & 0.0006 & 0.001 \\
Paramecium aurelia & 0.0032 & 5 & 0.0012 & 0.0401 & 0.4186 \\
Tachysoma pellionellum & 0.0064 & 5 & 0.0415 & 4.5041 & 0.8311 \\
Tetrahymena pyriformis & 0.2079 & 5 & & 0.0048 \\
\hline
\end{tabular}

Error $d f=24$

Table 4 Mean ingestion rates of ciliate numbers and biomass by different developmental stages of the copepod

\begin{tabular}{lllllrr}
\hline Ingestion rate & Exp. & $\mathrm{N}-1$ & $\mathrm{~N}-2$ & $\mathrm{C}-1$ & $\mathrm{C}-2$ & Adult \\
\hline Ciliates copepod $^{-1} \mathrm{~h}^{1}$ & 1 & 6.39 & 18.17 & 11.62 & 22.59 & 18.91 \\
& 2 & 8.39 & 12.86 & 11.55 & 9.67 & 9.60 \\
$\mu \mathrm{g} \mathrm{C} \mathrm{copepod}^{-1} \mathrm{~h}^{-1}$ & 1 & 0.005 & 0.032 & 0.036 & 0.088 & 0.134 \\
& 2 & 0.008 & 0.013 & 0.031 & 0.037 \\
\hline
\end{tabular}

Values estimated separately from experiments 1 and 2

benefit. It is a well known fact that the preference for a given prey may be affected by the relative abundance of alternative prey. Reiss \& Schmid-Araya (2011) demonstrated that the adult Eucyclops serrulatus selected for the larger ciliate from the two species available only when the large species was present in high numbers. This allowed E. serrulatus to maximize its nutritional benefit in spite of the longer handling times of the larger prey. The ingestion rates observed for the adult harpacticoid in the present study (Table 4) are within the range measured by Rieper
(1985) for a marine harpacticoid (11-65 ciliates copepod $^{-1} \mathrm{~h}^{-1}$ ) and that reported by Reiss \& Schmid-Araya (2011) for E. serrulatus (3-69 ciliates copepod $\left.^{-1} \mathrm{~h}^{-1}\right)$.

An interesting result of the present study is the observation that the ciliate Colpoda inflata seemed to produce more cysts in those treatments where predation was more intense. Ciliates from the genus Colpoda are well known for their great capacity for encystation. They are most abundant in soil and litter habitats (Bamforth, 1977). Colpoda ciliates were 
sometimes observed to be able to undertake activity in minutes after the re-appearance of water. Although it is clearly an adaptation to the frequent drying out of habitats, the encystation may also reduce the risk of predation, at least for some type of predators. It has been demonstrated that some Daphnia species produce summer resting eggs in response to the presence of fish, and it is interpreted as a predator-induced defence mechanism (Pijanowska \& Stolpe, 1996). Fyda et al. (2005) observed significantly higher rates of encystations of Euplotes muscorum in treatments with predatory ciliates Dileptus anser and Spathidium sp. The cysts of Colpoda may be more difficult to ingest due to thick mucus walls making them adhere to substratum (Kida \& Matsuoka, 2006). Also, it has been shown that cysts of Colpoda can survive in digestive tube of some consumers (Fernandez-Galiano et al., 1986). One cannot exclude that the observed higher rate of encystation in $C$. inflata under higher predation risk is a kind of predator-induced defence, but such a hypothesis would need to be verified with separate experiments.

The fact that no predation effects could be observed on Tachysoma pellionellum or Paramecium aurelia was rather unexpected. The results might suggest that due to their size these ciliates were beyond the reach of our copepod. In the case of T. pellionellum, both size and behaviour could be responsible for the lack of predation. Tachysoma pellionellum was the only species to spend most of the time crawling on surfaces, in contrast to the remaining species which were mainly swimming in the water column. To our knowledge, no data are available from benthic habitats linking ciliate locomotory behaviour with the performance of their copepod predators. It is noteworthy, however, that the crawling ciliate Euplotes sp. (length 20-30 $\mu \mathrm{m}$ ) was not ingested by the marine harpacticoid Tisbe holothuriae in a feeding experiment described by Rieper (1985).

Paramecium aurelia was the largest ciliate in this experiment. Nevertheless, the adult harpacticoid preyed very efficiently upon $C$. kleini whose cell length was only about $1 / 3$ smaller than that of $P$. aurelia. The cortex of Paramecium cells contains a layer of trichocysts, i.e. special organelles that extrude explosively in response to mechanical or chemical stimuli. Haramuto \& Miyake (1991) have demonstrated that Paramecium trichocysts ensure effective defence against a predatory ciliate Dileptus margaritifer. Recently, Buonanno et al. (2013) provided evidence that trichocysts of Paramecium tetraurelia were also efficient against some metazoan predators such as the rotifer Cephalodella sp. and the ostracod Eucypris sp. but not against the platyhelminth Stenostomum sphagnetorum. Although the possible effectiveness of Paramecium trichocysts against harpacticoids remains to be investigated, it is well known that at least some cyclopoid species do feed on Paramecium (Reiss \& Schmid-Araya, 2011). Also, some cyclopoid species of similar size to our copepod can be reared in mass culture on a diet containing Paramecium caudatum (Suarez et al., 1992).

The genus Paramecium has been reported from Heliconia and Calathea bract containers by several authors (Laessle, 1961; Maguire \& Belk, 1967; Maguire et al., 1968, Vandermeer et al., 1972). It remains unknown, however, why this genus seems to be absent from tank bromeliads in the same area (Vandermeer et al., 1972; Dunthorn et al., 2012). Although Paramecium ciliates are easily eliminated from Heliconia bracts by mosquito larvae (Maguire et al., 1968), our results demonstrate that they may not be readily available for copepods living in these habitats.

The observations provided by the present study on a freshwater harpacticoid feeding on various ciliate species add to the limited knowledge on the trophic function of benthic copepods, i.e. one of the most important components of the freshwater meiofauna. Our results may also be useful for the future studies on phytotelmata, in particular on Calathea and Heliconia bract containers that offer interesting possibilities for testing hypotheses in the field of community ecology. Phytotelmata possess most of the advantages usually attributed to laboratory microcosms, being natural systems inhabited by communities of organisms that evolved together under natural dispersal rates (Srivastava et al., 2004).

Acknowledgments This work was done in the frame of the Tropical ecology field course organized by the Institute of Environmental Sciences, Jagiellonian University (Poland) together with Universidad Central in Maracay and Instituto Venezolano de Investigaciones Cientificas (Venezuela). We thank Carlos Loucho and Juan Garcia for their good humour and great help during the course at the Biological Station in Rancho Grande, Venezuela. Dr. Eduardo Suarez-Morales is thanked for discussing possible identity of the copepod. Alan Warren helped to edit the text. This work was financially supported by the Jagiellonian University Grant DS/WBiNoZ/INoŚ/757. 
Open Access This article is distributed under the terms of the Creative Commons Attribution 4.0 International License (http:// creativecommons.org/licenses/by/4.0/), which permits unrestricted use, distribution, and reproduction in any medium, provided you give appropriate credit to the original author(s) and the source, provide a link to the Creative Commons license, and indicate if changes were made.

\section{References}

Addicott, J. F., 1974. Predation and prey community structureexperimental study of the effect of mosquito larvae on protozoan communities of pitcher plants. Ecology 55: $475-492$.

Azovsky, A. I., M. A. Saburowa, E. S. Chertoprood \& I. G. Polikarpov, 2005. Selective feeding of littoral harpacticoids on diatom algae: hungry gourmands? Marine Biology 148: 327-337.

Bamforth, S. S., 1977. Litters and Soils as Freshwater Ecosystems. In Cairns, J. J., (ed.), Aquatic Microbial Communities. Garland Reference Library of Science and Technology, Vol. 15. Garland Publishing Inc., New York: 243-256.

Buonanno, F., T. Harumoto \& C. Ortenzi, 2013. The defensive function of trichocysts in Paramecium tetraurelia against metazoan predators compared with the chemical defense of two species of toxin-containing ciliates. Zoological Science 30: 255-261.

Calbet, A. \& E. Saiz, 2005. The ciliate-copepod link in marine ecosystems. Aquatic Microbial Ecology 38: 157-167.

Chepurnov, V. A., 1987. On the role of benthic diatom algae in feeding of harpacticoids (Copepoda) (in Russian). Zoologicheskiy Zhurnal 66: 1005-1012.

Cnudde, C., 2013. Trophic ecology of intertidal harpacticoid copepods, with emphasis on their interactions with bacteria. Ghent Unversity (UGent), 209 pp.

De Troch, M., M. B. Steinarsdóttir, V. Chepurnov \& E. Ólafsson, 2005. Grazing on diatoms by harpacticoid copepods: species-specific density-dependent uptake and microbial gardening. Aquatic Microbial Ecology 39: 135-144.

De Troch, M., V. Chepurnov, H. Gheerardyn, A. Vanreusel \& E. Ólafsson, 2006. Is diatom size selection by harpacticoid copepods related to grazer body size? Journal of Experimental Marine Biology and Ecology 332: 1-11.

Decho, A. W. \& J. W. Fleeger, 1988. Ontogenetic shifts in the meiobenthic harpacticoid copepod Nitocra lacustris. Marine Biology 97: 191-197.

Dunthorn, M., T. Stoeck, K. Wolf, H.-W. Breiner \& F. Foissner, 2012. Diversity and endemism of ciliates inhabiting Neotropical phytotelmata. Systematics and Biodiversity 10: 195-205.

Epp, R. W. \& W. M. Lewis Jr., 1980. The nature and ecological significance of metabolic changes during the life history of copepods. Ecology 61: 259-264.

Fernandez-Galiano, M. T., D. Fernandez-Galiano \& M. J. Madrigal-Sesma, 1986. Presence of viable cysts of Colpoda (Ciliophora Colpodida) in digestive tube of reptiles and amphibians. Revista Ibérica de Parasitología 46: 223-228.

Foissner, W., 1991. Basic light and scanning electron microscopic methods for taxonomic studies of ciliated protozoa. European Journal of Protistology 27: 313-330.

Foissner, W., 2010. Life cycle, morphology, ontogenesis, and phylogeny of Bromeliothrix metopoides nov. gen., nov. spec., a peculiar ciliate from tank bromeliads. Acta Protozoologica 49: 159-193.

Foissner, W., 2013. Description of Glaucomides bromelicola $\mathrm{n}$. gen., n. sp. (Ciliophora, Tetrahymenida), a macrostome forming inhabitant of bromeliads (Bromeliaceae), including redescriptions of Glaucoma scintillans and G. reniformis. Journal of Eukaryotic Microbiology 60: 137-157.

Foissner, W. \& T. Stoeck, 2013. Morphology of Bromeliophrya quadristicha n. spec., an inhabitant of tank bromeliads (Bromeliaceae), and phylogeny of the Bromeliophryidae (Ciliophora, Tetrahymenida). Journal of Eukaryotic Microbiology 60: 223-234.

Foissner, W., H. Berger \& F. Kohmann, 1991. Taxonomische und ökologische Revision der Ciliaten des Saprobiensystems. Band I: Cyrtophorida, Oligotrichida, Hypotrichia, Colpodea. Informationsberichte des Bayer. Landesamtes fur Wasserwirtschaft Heft 1/91: 1-467

Foissner, W., H. Berger \& F. Kohmann, 1994. Taxonomische und ökologische Revision der Ciliaten des Saprobiensystems. Band III: Hymenostomata, Prostomatida, Nassulida. Informationsberichte des Bayer. Landesamtes fur Wasserwirtschaft Heft 1/94: 1-543

Foissner, W., M. Strüder-Kypke, G. W. M. van der Staay, S.-Y. Moon-van der Staay \& J. H. P. Hackstein, 2003. Endemic ciliates (Protozoa, Ciliophora) from tank bromeliads: a combined morphological, molecular, and ecological study. European Journal of Protistology 39: 365-372.

Foissner, W., K. Wolf, S. Kumar, K. Xu \& P. Quintela-Alonso, 2014. Five new spathidiids (Ciliophora: Haptorida) from Caribbean tank bromeliads. Acta Protozoologica 53: 159-194.

Frank, J. H., 1983. Bromeliad Phytotelmata and Their Biota, Especially Mosquitoes. p. 101-128. In Frank, J. H. \& L. P. Lounibos (eds), Phytotelmata: Terrestrial Plants as Hosts for Aquatic Insect Communities. Plexus Publ, Medford: 293.

Frank, J. H. \& L. P. Lounibos (eds), 1983. Phytotelmata: Terrestrial Plants as Hosts for Aquatic Insect Communities. Plexus, Medford (New Jersey): 293 pp.

Fyda, J., A. Warren \& J. Wolińska, 2005. An investigation of predator-induced defence responses in ciliated protozoa. Journal of Natural History 39: 1431-1442.

Greeney, H. F., 2001. The insects of plant-held waters: a review and bibliography. Journal of Tropical Ecology 17: 241-260.

Haramuto, T. \& A. Miyake, 1991. Defensive function of trichocysts in Paramecium. Journal of Experimental Zoology 206: 84-92.

Hicks, G. R. F. \& B. C. Coull, 1983. The ecology of marine meiobenthic harpacticoid copepods. Oceanography and Marine Biology Annual Reviews 21: 67-175.

Jocque, M., F. Fiers, M. Romero \& K. Martens, 2013. Crustacea in phytotelmata: a global overview. Journal of Crustacean Biology 33: 451-460. 
Kida, A. \& T. Matsuoka, 2006. Cyst wall formation in the ciliated protozoan Colpoda cucullus: cyst wall is not originated from pellicle membranes. Invertebrate Survival Journal 3: 77-83.

Kiørboe, T. \& A. W. Visser, 1999. Predator and prey perception in copepods due to hydromechanical signals. Marine Ecology Progress Series 179: 81-95.

Kitching, R. L., 2000. Food Webs and Container Habitats: The Natural History and Ecology of Phytotelmata. Cambridge University Press, Cambridge.

Kumar, R. \& T. R. Rao, 1998. Post-embryonic developmental rates as a function of food type in the cyclopoid copepod, Mesocyclops thermocyclopoides Harada. Journal of Plankton Research 20: 271-287.

Laessle, A. M., 1961. A micro-limnological study of Jamaican bromelliads. Ecology 42: 499-517.

Maguire, B., 1963. The exclusion of Colpoda (Ciliata) from superfically favorable habitats. Ecology 44: 781-784.

Maguire, B., 1971. Phytotelmata: biota and community structure determination in plant-held waters. Annual Review of Ecology and Systematics 2: 439-464.

Maguire, B. \& D. Belk, 1967. Paramecium transported by land snails. Journal of Protozoology 14: 445-447.

Maguire, B., D. Belk \& G. Wells, 1968. Control of community structure by mosquito larvae. Ecology 49: 207-210.

Muylaert, K., L. Zhao, K. Van der Gucht, S. Cousin, S. Declerck \& W. Vyverman, 2006. Trophic coupling in the microbial food web of a eutrophic shallow lake (Lake Visvijver, Belgium). Archiv für Hydrobiologie 166: 307-324.

Naeem, S., 1988. Predator-prey interactions and community structure: chironomids, mosquitos and copepods in Heliconia imbricata (Musaceae). Oecologia 77: 202-209.

Perlmutter, D. G. \& J. L. Meyer, 1991. The impact of a streamdwelling harpacticoid copepod upon detritally associated bacteria. Ecology 72: 2170-2180.

Pijanowska, J. \& G. Stolpe, 1996. Summer diapause in Daphnia as a reaction to the presence of fish. Journal of Plankton Research 18: 1407-1412.

Reiss, J. \& J. M. Schmid-Araya, 2011. Feeding response of a benthic copepod to ciliate prey type, prey concentration and habitat complexity. Freshwater Biology 56: 1519-1530.

Richardson, B. A., 1999. The bromeliad microcosm and the assessment of faunal diversity in a neotropical forest. Biotropica 31: 321-326.

Rieper, M., 1985. Some lower food web organisms in the nutrition of marine harpacticoid copepods: an experimental study. Helgoländer Meeresuntersuchungen 39: 357-366.
Rieper, M. \& C. Flotow, 1981. Feeding experiments with bacteria, ciliates and harpacticoid copepods. Kieler Meeresforschungen Sonderheft 5: 370-375.

Sarvala, J., 1998. Ecology and role of benthic copepods in northern lakes. Journal of Marine Systems 15: 75-86.

Seifert, R. P., 1980. Mosquito fauna of Heliconia aurea. Journal of Animal Ecology 49: 687-697.

Seifert, R. P. \& F. H. Seifert, 1979. A Heliconia insect community in a Venezuelan cloud forest. Ecology 60: 462-467.

Sherr, E. B., B. F. Sherr \& G. A. Paffenhöfer, 1986. Phagotrophic protozoa as food for metazoans: a 'missing' trophic link in marine pelagic food webs? Marine Microbial Food Webs 1: 61-80.

Srivastava, D. S., J. Kolasa, J. Bengtsson, A. Gonzalez, S. P. Lawler, T. E. Miller, P. Munguia, T. Romanuk, D. C. Schneider \& M. K. Trzcinski, 2004. Are natural microcosms useful model systems for ecology? Trends in Ecology \& Evolution 19: 374-384.

Suarez, M. F., G. G. Marten \& G. C. Clark, 1992. A simple method for cultivating freshwater copepods used in biological control of A. aegypti. Journal of the American Mosquito Control Association 8: 409-412.

Sugden, A. M. \& R. J. Robins, 1979. Aspects of the ecology of vascular epiphytes in Colombian cloud forests, I. The distribution of the epiphytic flora. Biotropica 11: 173-188.

Vandermeer, J., J. Addicott, A. Andersen, J. Kitasako, D. Pearson, Ch. Schnell \& H. Wilbur, 1972. Observation on Paramecium occupying arboreal standing water in Costa Rica. Ecology 53: 291-293.

Wiackowski, K., M. T. Brett \& C. R. Goldman, 1994. Differential effects of zooplankton species on ciliate community structure. Limnology and Oceanography 39: 486-492.

Wickham, S. A., 1995a. Trophic relations between cyclopoid copepods and ciliated protists: complex interactions link the microbial and classic food webs. Limnology and Oceanography 40: 1173-1181.

Wickham, S. A., 1995b. Cyclops predation on ciliates: species specific differences and functional responses. Journal of Plankton Research 17: 1633-1646.

Wyckmans, M., V. A. Chepurnov, A. Vanreusel \& M. De Troch, 2007. Effects of food diversity on diatom selection by harpacticoid copepods. Journal of Experimental Marine Biology and Ecology 345: 119-128. 